\title{
Uso do fixador externo no tratamento das fraturas cominutivas da extremidade distal do rádio
}

\author{
The use of external fixator in the treatment of comminuted \\ fractures of the distal radius
}

\begin{abstract}
Cláudio Henrique Barbieri , Nilton Mazzer ${ }^{2}$, Ricardo José Cabello ${ }^{3}$, Emerson luiz Cardia de Campos ${ }^{3}$, VaLÉRIA MEIRELLES CARRIL ELUI"
\end{abstract}

\section{RESUMO}

Foi realizado um estudo combinado retrospectivo e de reavaliação de uma população original de 60 pacientes, somando 64 fraturas da extremidade distal do rádio submetidas ao tratamento pelo método da fixação externa, num período de dez anos (janeiro 86 a janeiro 96). Foram estudados retrospectivamente 46 pacientes com 50 punhos. Compareceram para reavaliação 32 pacientes, totalizando 35 punhos. No estudo retrospectivo, foi realizada a medida dos parâmetros ângulo radial, ângulo volar, comprimento relativo do rádio, ângulo escafo-semilunar, ângulo luno-capitato e sinal do anel no escafóide, nas radiografias finais do seguimento dos pacientes. Na reavaliação, além dos parâmetros clínicos e funcionais, a medida da diastase escafosemilunar em incidência radiográfica especial foi adicionada aos parâmetros radiográficos previamente estudados. Os resultados mostraram que o método da fixação externa restabelece a anatomia da extremidade distal do rádio, propiciando bons resultados clínicos e funcionais na maior parte dos pacientes, com baixo índice de complicações.

Descritores: Fratura cominutiva; Extremidade distal do rádio; Fixação externa

\section{INTRODUÇÃO}

As fraturas da extremidade distal do rádio são de ocorrência bastante comum. A maior parte dessas fraturas se prestam ao tratamento conservador, seja com aparelho gessado ou com outros métodos de imobilização que, em geral, produzem bons resultados. ${ }^{(1,11,13,24,27,29,30)}$ Entretanto, algumas dessas fraturas, principalmente as que apresentam cominuição, traços intraarticulares e grandes desvios, representam um desafio ao tratamento conservador, dada a dificuldade em obter e manter uma redução que restabeleça a congruência articular e produza resultados clínicos e funcionais satisfatórios. . $1,3,5,14,16,24,27,28,30,31)$

\section{SUMMARY}

A combined retrospective and survey study of an original population of 60 patients, summing up 64 comminuted fractures of the distal radius treated by external fixation in a ten-year period (January 86 to January 96) was carried out. Forty-six patients summing up 50 wrists were retrospectively studied and 32 patients with 35 wrists were reviewed. In the retrospective study the parameters radial angle, volar angle, relative length of the radius, scapholunate angle, lunocapitate angle and scaphoid ring sign were measured in the final X-ray controls of all patients. In the survey study, apart from the clinical and functional evaluation, the measurement of the scapholunate diastasis, as observed in a special X-ray view, was added to the radiological evaluation. The results showed that the method of external fixation restores the anatomy of the distal end of the radius, so as to produce good clinical and functional results in the majority of the cases, with a low complication rate.

Key Words: Comminuted fracture; distal end of radius; external fixation

\section{INTRODUCTION}

Radial distal end fractures are very common. Most of them are suitable for conservative treatment, under plaster or other immobilization means with generally good results. $(1,11,13,24,27,29,30)$.

Some of these fractures, however, particularly those presenting comminution, articular involvement and significant deviation are a real challenge for conservative treatment due to difficulty in obtaining and keeping an adequate reduction in terms of anatomy and clinically satisfactory results. ${ }^{(1,3,5,14,16,24,27,28,30,31)}$
Serviço de Cirurgia da Mão e do Membro Superior e Microcirurgia do Hospital das Clínicas de Ribeirão Preto, Disciplina Ortopedia e Traumatologia da Faculdade de Medicina de Ribeirão Preto - USP - CEP 14048-900 Ribeirão Preto SP

1 - Professor titular

2 - Professor associado

3 - Médico residente R4
Hand and Upper Limb Surgery and Microsurgery Service - Hospital das Clínicas de Ribeirão Preto, Disciplina Ortopedia e Traumatologia da Faculdade de Medicina de Ribeirão Preto - USP. - 14048-900 Ribeirão Preto SP

1 Titular Professo

3 Resident R4
2 Associate Professor 4 Ocupational Therapist

Trabalho recebido em 13/04/2000. Aprovado em 05/08/2000 
Inúmeros autores introduziram métodos alternativos, em geral mais agressivos do que a simples redução pela manipulação externa, com a finalidade de manter a redução obtida com maior eficiência. Assim, já na década de 20, Boehler ${ }^{(8)}$ introduziu a técnica de tração-fixação bipolar, utilizando fios de Kirschner ou pinos de Steinmann passados percutaneamente, um no rádio, num local proximal ao da fratura, e o outro nos metacárpicos. Após a tração e redução dos fragmentos, obtidas por meio de estribos, um aparelho gessado era confeccionado, englobando os dois fios.

A técnica de Boehler foi modificada posteriormente por outros autores $^{(16,18,25,28,30,31)}$, sendo que a característica comum a todas as modificações é que o conjunto pino-gesso mantém uma tensão nos ligamentos rádio-cárpicos (ligamentotaxia), possibilitando uma redução mais adequada e estável de eventuais fragmentos intra-articulares, sem a necessidade de cirurgia aberta ${ }^{(5)}$. Apesar dos bons resultados relatados pelos diversos autores, todos os métodos que utilizam a combinação pinogesso apresentam alguns inconvenientes, como a infecção do trajeto do pino, que permanece encoberto pelo gesso e impossibilitado de ser higienizado, e a dificuldade de remanipulação no caso de perda da redução, que exige a remoção do gesso. ${ }^{(5,10,16)}$

Tais inconvenientes levaram ao desenvolvimento do fixador externo, no qual uma armação metálica leve desempenha o papel do aparelho gessado, mantendo os pinos sob tensão. Posteriormente ao trabalho de Anderson e O'Neil(2), outros autores estudaram o método da fixação externa, alguns propondo outros tipos de fixadores externos ${ }^{(3,7,12,20,23,26)}$, referindo bons resultados e baixos índices de complicações devidas ao aparelho. De fato, o seu emprego eliminou as desvantagens da combinação pino-gesso, pois os fios expostos podem ser facilmente higienizados e a remanipulação é relativamente fácil, qualquer que seja o modelo utilizado, características que contribuíram para dar ao método aceitação universal.

Entretanto, nem sempre a ligamentotaxia obtida com o fixador externo é suficiente para produzir e manter a redução dos múltiplos fragmentos de fraturas muito cominuídas, que costumam envolver tanto a articulação rádio-cárpica como a rádio-ulnar distal. Nesses casos, ela deve ser associada com a fixação com fios de Kirschner, introduzidos por via percutânea ou após redução cruenta dos fragmentos articulares, com ou sem o uso simultâneo de enxerto de osso esponjoso. . $^{(3,20,21,23,26)}$

Já em meados da década de 80, o método da fixação externa, combinada ou não com a fixação com fios de Kirschner, foi padronizado pelos autores (CHB e NM) para o tratamento das fraturas cominutivas da extremidade distal do rádio, dos tipos 7 e 8 da classificação de Frykman. ${ }^{(15)}$ Os resultados imediatos da utilização do método sempre pareceram bons aos autores, conclusão baseada apenas nas observações dos seguimentos ambulatoriais dos pacientes operados. Entretanto, não eram conhecidos os resultados tardios da sua aplicação, mesmo porque os pacientes recebiam alta ambulatorial no máximo seis meses após a fratura.
Many authors have presented alternative methods, generally more aggressive than plain reduction by external manipulation aiming to keep the reduction achieved. So, already in the twenties Boehler ${ }^{(8)}$ introduced the bipolar traction/fixation using two percutaneous Kirschner wires or Steinmann nails, one placed in the radius, close to the fracture, and the other one in the metacarpals. After traction and reduction of the fragments, a plaster cast was placed involving the wires.

Boehler's technique was also modified by some other authors. $(16,18,25,28,30,31)$, being the common aspect of all modifications the maintenance of tension in the radio-carpal ligaments allowing a more stable and adequate reduction of eventual intra-articular fragments avoiding open surgery. ${ }^{(5)}$. Even though good results reported by many authors, all methods using wire and cast bring some inconveniences such as infection at the pin placement, which remains covered by the cast, making impossible to clean the skin wound. In case of loosening of reduction it is also difficult to re-manipulate, requesting the cast model to be removed. $(5,10,16)$.

The existence of these inconveniences lead to the development of external fixators, in which a light metallic frame plays the role of the cast model, keeping the wires under tension. After Anderson and O'Neil's work (2), other authors studied the external fixation method, some proposing other models of external fixator $(3,7,12,20,23,26)$, reporting good results and low related to the fixator complication rates. In fact, its use avoided the disadvantages of wire and cast combination, since the exposed wires can be easily cleaned and re-manipulation is relatively easy to perform with any model of fixator, what contributed to bring an universal acceptance to the method.

However it is not always that ligament traction obtained by means of the external fixator is enough to produce and keep reduction of the several fragments of very much comminuted fractures, which use to involve both radio-carpic and radio-ulnar joints. In these cases, it should be added of a percutaneous Kirschner wire fixation, or, after an open reduction of articular fragments with or without bone grafting. ${ }^{(3,20,21,23,26)}$.

By the middle of the eighties, the external fixation method combined or not to Kirschner wires fixation was standardized by the authors (CHB e NM) for the treatment of comminuted fractures of distal radius Frykman grade 7 and $8^{(15)}$. Immediate results of the method always looked good to the authors, and this conclusion was based only on ambulatory follow-up of patients submitted to the method. However, late results were not yet known, even because all patients were discharged from followup no longer than 6 months after the fracture.

For this reason, the objective of this work was to evaluate the late results of the method in 50 wrists of 46 patients treated over a period of 10 years with emphasis on functional recovery in comparison to the anatomical result as evaluated by roentgen examination. 
Foi, então, o objetivo do presente trabalho avaliar os resultados tardios da aplicação do método em 50 punhos de 46 pacientes, tratados num período de dez anos, com ênfase na recuperação funcional em comparação ao resultado anatômico, como observado ao exame radiográfico.

\section{MATERIAL E MÉTODOS}

O trabalho desenvolveu-se em duas etapas. Na primeira, foi realizada uma análise retrospectiva de todos os casos de fraturas da extremidade distal do rádio tratadas pelo método de ligamentotaxia com o fixador externo, catalogados no período de janeiro de 1986 a janeiro de 1996. Na segunda, os pacientes selecionados foram convocados para reavaliação dos resultados tardios do tratamento.

\section{Análise retrospectiva}

Na análise retrospectiva, foram localizados 60 pacientes, totalizando 64 punhos (quatro bilaterais), dentre os quais foram excluídos 14 , em virtude de óbito, perda de seguimento ou documentação incompleta, restando 46 pacientes e 50 punhos (quatro bilaterais) efetivamente avaliados. Desse contingente, 26 eram homens e 20 eram mulheres, com idade variando entre 20 e 88 anos (média: 51,9 anos). Quanto ao lado afetado, 27 fraturas ocorreram no lado dominante e 15 no lado contralateral, além de quatro fraturas bilaterais (oito punhos).

A causa predominante do trauma foi a queda da própria altura (24 casos, ou 48\%), seguida por acidente motociclístico (oito casos, $16 \%$ ), queda de grande altura (cinco casos, $10 \%$ ), acidente automobilístico (quatro casos, $8 \%$ ) e atropelamento (dois casos, $4 \%$ ). Sete casos (14\%) resultaram de traumatismos de outra natureza, em geral por agente direto, como agressão com porrete ou acidente com maquina industrial. Acometimento de outros sistemas ocorreu em 21 pacientes (45,5\%), incluindo doze lesões em outros segmentos do aparelho locomotor, nove traumatismos crânio-encefálicos e quatro em outros órgãos.

A análise retrospectiva das radiografias incluiu: 1) classificação das fraturas segundo Frykman ${ }^{(15)}$ (Tabela 1); 2) estudo dos desvios angulares (ângulos de desvio radial e dorsal) e do encurtamento radial, segundo os critérios anatômicos de Frykman modificados por Lidström ${ }^{(22,29)}$; e 3) sinais de instabilidade cárpica, conforme medidos nas radiografias realizadas no dia do primeiro atendimento e no último atendimento realizado de rotina (figura 1 ).

\section{MATERIAL E METHODS}

The work was developed in two phases. In the first one, it was performed a retrospective analysis of all cases of distal radius fractures treated by means of ligamental traction with an external fixator recorded from January 1986 to January 1996. In the second, selected patients were recalled for reevaluation of late treatment results.

\section{Retrospective Analysis}

In the retrospective analysis 60 patients were found, performing 64 wrists (four were bilateral) and 14 were dropped out due to death, lack of follow-up or incomplete documentation. The remaining 46 patients represented 50 wrists (4 bilateral) effectively evaluated. From these patients, 26 were male and 20 female, the age ranging from 20 to 88 years old (average 51.9 years). Regarding the affected side, 27 were at the dominant side and 15 at non-dominant side, and 4 were bilateral (8 wrists).

The most common cause was falling form standing position (24 cases, or 48\%), followed by motorcycle accident (8 cases, $16 \%$ ), fall from high (five cases, 10\%), automobile accident (four cases, 8\%) and running over (two cases, $4 \%$ ). Seven cases $(14 \%)$ resulted of other kinds of traumatism, generally by direct agent such as aggression with a stick or industrial machinery accident. Other body systems were affected in 21 patients (45.5\%) including twelve injuries in other parts of the limbs, nine brain injury and
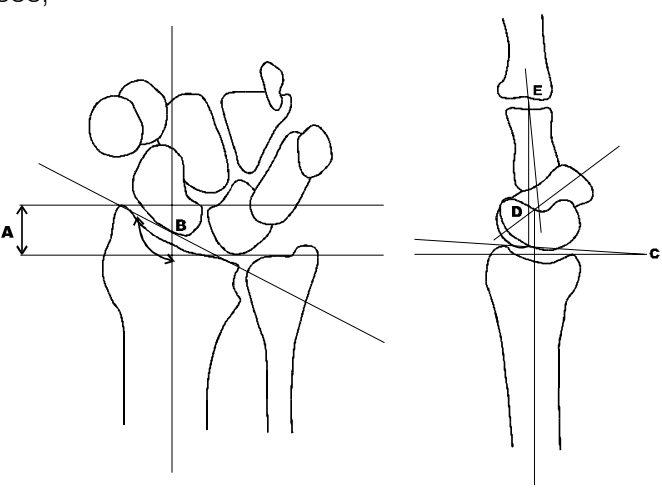

Figura 1: Representação esquemática dos parâmetros analisados na avaliação radiográfica. A. Comprimento relativo do rádio; B. Ângulo radial; C. Ângulo volar; D. Ângulo escafo-semilunar; e E. Ângulo luno-capitato. Figure 1: Schematic drawing of the parameters used in radiographic evaluation. A. Relative length of radius. $B$. radial angle. C. Volar angle. $D$. scapholunate angle and E. lunocapitate angle. four in other organs.

The retrospective analysis of the X-ray examinations included: 1) Fracture classification according to Frykman (15) (Table 1); 2) study of angle deviations (radial and dorsal deviation angles) and radial shortening according to Frykman's anatomical criteria as modified by Lidström ${ }^{22,29)}$; and 3) signs of carpal instability according to $X$-ray exams performed on the first assistance and at the last routine visit (Figure 1). 


\section{Reavaliação dos pacientes}

Na segunda etapa, todos os 46 pacientes cujos prontuários haviam sido analisados retrospectivamente, foram convocados, tendo comparecido 32, que foram submetidos a avaliação clínica, radiológica e funcional, totalizando 35 punhos com seguimento médio de 46,6 meses (variação: 9 - 105 meses).

Na avaliação clínica os pacientes foram inicialmente questionados quanto a possíveis queixas, como dor (em repouso, aos esforços e à mudança de temperatura), restrições das atividades e parestesias, e ao grau de satisfação com o resultado do tratamento. Em seguida, foram examinados quanto às condições locais da pele (edema, coloração e trofismo) e possíveis alterações estéticas, e à amplitude de movimentos do punho, do cotovelo e do ombro, através de goniometria dessas articulações. Além da avaliação clínica, os pacientes foram submetidos à avaliação funcional do membro superior, segundo o protocolo de Carazatto ${ }^{(9)}$, complementado pelas medidas da força de preensão da mão e de pinça polegar-indicador, utilizando, respectivamente, um dinamômetro manual (Jamar) e um dinamômetro de pinça.

A avaliação radiológica dos punhos compreendeu as incidências convencionais em póstero-anterior e lateral, complementadas com uma incidência póstero-anterior com inclinação ulno-radial de $10^{\circ}$ da ampola, para avaliação das relações entre o escafóide e o semilunar e para eventual demonstração de instabilidade nos ossos do carpo ${ }^{(4,17)}$. Na radiografias obtidas, foram analisados os seguintes parâmetros: 1) ângulo de inclinação radial; 2) ângulo de inclinação volar; 3) discrepância de comprimento rádio-ulnar; 4) diastase escáfo-semilunar; 5) ângulo escafo-semilunar; 6) ângulo luno-capitato; 7) sinal do anel no escafóide; e 8) sinais sugestivos de degeneração e artrose (figura 1).

\section{Técnica operatória}

A técnica operatória empregada foi a preconizada pelo grupo AO. Sob anestesia geral ou bloqueio do plexo braquial, o membro afetado era preparado da maneira convencional para uma operação aberta. Um garrote era instalado somente nos casos em que a redução aberta tivesse sido indicada de antemão. Tração manual era aplicada por 10 minutos, acompanhada de manobras de compressão bidigital do local da fratura e de extensão e flexão do punho, para liberar os fragmentos ósseos impactados. Em seguida, o fixador externo era aplicado. Em todos os casos, foi utilizado um fixador externo específico para punho, de fabricação nacional (Biomecânica).

Inicialmente, eram inseridos dois pinos de Shanz na face dorsoradial do rádio e dois na face dorso-radial do segundo metacárpico, orientados segundo um ângulo de $45^{\circ} \mathrm{com}$ os planos frontal e sagital do antebraço ${ }^{(23)}$. Os fios eram passados transversalmente à superfície do osso e paralelos entre si nos dois ossos, distando um do outro cerca de $3 \mathrm{~cm}$, no rádio, e $1,5 \mathrm{~cm}$, no metacárpico, conforme o molde da própria plataforma de fixação. Para o rádio, eram utilizados fios de $3 \mathrm{~mm}$ de diâmetro, e para os metacárpicos, de 2,5 mm de diâmetro, sendo todos com o comprimento de 80 $\mathrm{mm}$. A inserção dos pinos de Shanz, que eram introduzidos manualmente com um introdutor em "T", era precedida pela perfuração dos orifícios, com broca de diâmetro 0,5 mm menor do

\section{Patients re-evaluation}

In the second part, all 46 patients whose files were previously evaluated were recalled. Thirty-two came and undergone roentgen, functional and clinical evaluation in a total of 35 wrists with a mean follow-up of 46.6 moths (range from 9 to 105 months).

During the clinical evaluation patients were inquired regarding complaints such as pain (at rest, during movement, at changes of temperature), activity restrictions, parestesias, and the degree of satisfaction with the result of the treatment. Following, they undergone local clinical examination regarding skin conditions (edema, color, trophism) and possible aesthetic changes, and range of movement of the wrist, the elbow and the shoulder through goniometry. Additionally, patients undergone an upper limb functional evaluation according to Carazatto's protocol (9), complemented by measurement of the strength of grip and thumb/ index strength using a hand dynamometer (Jamar) and a thumb/ index dynamometer.

Roentgen analysis of the wrists was performed by usual anteriorposterior and lateral views, with addition of a posterior-anterior view with an ulnar-radial angulation of the ampoule by $10^{\circ}$ in order to evaluate connections between scaphoid, lunatus and eventually display carpal bone instability. ${ }^{(4,17)}$ In the radiographic exams, it was evaluated: 1) radial angle; 2) volar angle; 3) rádio-ulnar length discrepancy; 4) scapholunate diastasis; 5) scapholunate angle; 6) lunocapitate angle; 7) scaphoid ring sign; e 8) signs suggesting arthrosis and degeneration (Figure 1).

\section{Operative Technique}

The technique used was the indicated by AO group. Under general or regional anesthesia, the affected limb was prepared as usual for an open surgery. A pneumatic tourniquet was installed only in these cases when open reduction was anticipated. Manual traction was applied for 10 minutes and maneuvers of digital compression of the fracture area, and flexion and extension of the wrist aiming to release impacted fragments. Then the external fixator was applied. In all cases an specific made in Brazil external wrist fixator was applied (Biomecanica).

Initially two Shanz nails were placed in dorso-radial aspect of radius and two in the second metacarpal with a $45^{\circ}$ orientation in regard to frontal and sagital forearm views. The nails were placed transversally to the bone surface and parallel to each other in the two bones, with a distance among them of about 3 $\mathrm{cm}$ in radius, and $1.5 \mathrm{~cm}$ in the metacarpal, according to the standard of the fixation platform. For the radius, were used wires of $3 \mathrm{~mm}$ diameter, and for the metacarpals of $2.5 \mathrm{~mm}$. All of them were $80 \mathrm{~mm}$ long. Shanz nail were inserted manually using a " $T$ " driver and preceded by a bone perforation by a drill with a diameter $0.5 \mathrm{~mm}$ smaller than the nail (respectively 2.5 and $2.0 \mathrm{~mm}$ ). This procedure avoids premature loosening of the nails.

When a satisfactory and stable reduction of the several fragments was not obtained, a percutaneous fixation with 


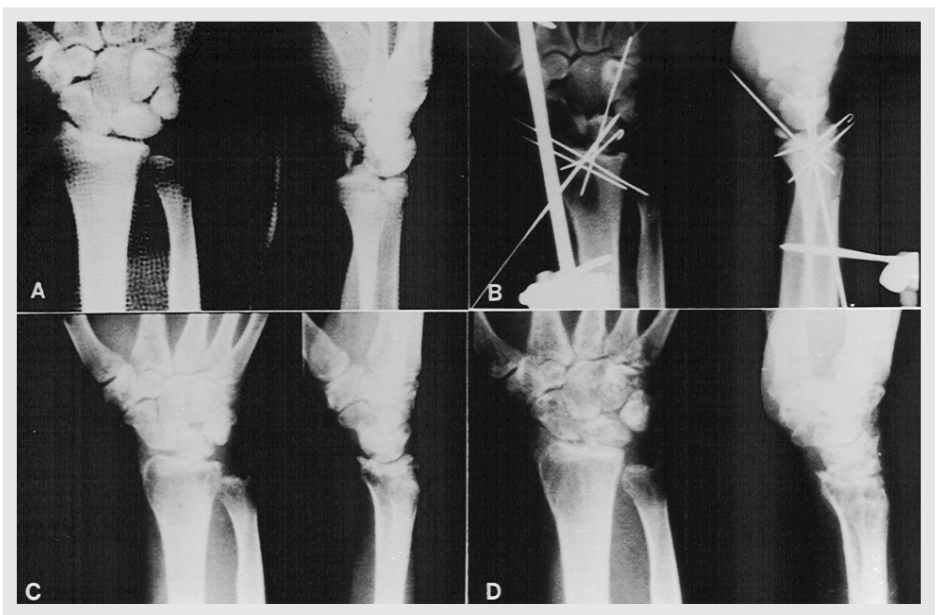

Figura 2: Seqüência radiográfica de um paciente submetido à redução aberta, clinicamente bem à época da reavaliação: A) radiografias pré-operatórias, mostrando subluxação volar do carpo; B) controle intra-operatório, fixação com múltiplos fios de Kirschner e fixador externo; C) controle de 3 meses, fratura consolidada, carpo alinhado; D) controle de 6 meses, carpo alinhado, certo grau de degeneração articular.

que o pino a ser utilizado (respectivamente, 2,5 $\mathrm{mm}$ e $2 \mathrm{~mm}$ ), procedimento que evita o afrouxamento prematuro dos pinos.

Nos casos em que não fosse conseguida a redução adequada e estável dos vários fragmentos, era realizada a fixação com fios de Kirschner percutâneos, sob visão do intensificador de imagens, ou mesmo a redução aberta e fixação com múltiplos fios de Kirschner, que não obedeciam a um padrão fixo, variando conforme o número e a posição dos fragmentos. A redução aberta era realizada através da incisão dorsal longitudinal ou, mais recentemente, da incisão trirradiada ${ }^{(6)}$. Assim, 21 pacientes (42\%) necessitaram da redução aberta, sendo que num deles foi em decorrência da perda da redução inicial (Figura 2).

O tempo decorrido entre o trauma e a realização da operação variou entre 1 e 28 dias (média: 10,5 dias). Já o período de manutenção da fixação externa variou de 3 a 11 semanas (média: 7,8 semanas), durante o qual o paciente era submetido a um protocolo de reabilitação que compreendia a mobilização ativa do ombro, cotovelo, antebraço e dos dedos, acompanhado semanalmente por um fisioterapêuta. A retirada do aparelho era sempre realizada em regime ambulatorial, com início imediato de fisioterapia para o punho

\section{RESULTADOS}

\section{Avaliação Clínica}

Dos 35 punhos reavaliados em 32 pacientes, 27 (77\%) eram inteiramente assintomáticos. Dentre os oito punhos restantes, um apresentava edema crônico, um tinha a pele distrófica e seis eram dolorosos ao repouso, aos esforços ou com mudanças climáticas. Restrição das atividades diárias foi detectada em 3 punhos.

A amplitude dos movimentos foi avaliada separadamente por
Figure 2: Radiographic sequence of a patient who underwent open reduction, clinically well by the time of re-evaluation. A) pre-operative radiographies, with volar carpal subluxation B) intra-operative control - fixation with several Kirschner wires and external fixators C) 3 maonths control - fracture is healed, and carpal alignment; D) 6 months control - carpal alignment, aand a certain degree of joint degeneration.

Kirschner wires was performed, using a scan or even an open reduction with multiple Kirschner wires fixation. This procedure did not follow a fixed pattern, but changed according to number and position of the fragments. Open reduction was performed through a dorsal longitudinal approach, a more recently a triradiated approach ${ }^{(6)}$. Twenty-one patients (42\%) needed open reduction, one of them in consequence of loosing the initial reduction. (Figure 2)

The time between the traumatism and the surgery ranged from 1 to 28 days (average: 10.5 days). The time under external fixation ranged from 3 to 11 weeks (average 7.8 weeks). During this time, patients underwent a rehabilitation protocol comprising active mobilization of the shoulder, elbow, forearm and fingers, with an weekly follow-up by a physiotherapist. Removal of the fixator was usually performed at the ambulatory followed by immediate start of wrist physiotherapy.

\section{RESULTS}

\section{Clinical Evaluation}

From the 35 wrists evaluated in 32 patients, 27 (77\%) had no symptom. Among the eight remaining wrists, one had chronic edema, one had dystrophic skin, six were painful at rest and at movement, or with changes in temperature. Daily activity restriction was found in 3 wrists.

Range of movement was separately evaluated, by plans using as standard the normal values described in the literature ${ }^{(13,18)}$, since eight patients had history of counter-lateral wrist fracture, making impossible making comparisons. So, extension was equal or superior to $80 \%$ of the normal in ten wrists, ranging from 60 to $80 \%$ in 14, from 40 to $60 \%$ in 11 and under $40 \%$ in six. 
planos, tendo como parâmetro os valores normais descritos na literatura ${ }^{(13,18)}$, uma vez que oito pacientes tinham história pregressa ou simultânea de fratura no punho contralateral, o que impedia comparações. Assim, a extensão era igual ou maior que $80 \%$ do normal em dez punhos, tendo variado de 60 a $80 \%$ em 14, de 40 a $60 \%$ em cinco e permanecido abaixo de $40 \%$ em seis.

A flexão era igual ou maior que $80 \%$ do normal em quatro punhos, tendo variado de 60 a $80 \%$ em 15, de 40 a 60\% em 11 e permanecido menor que $40 \%$ em cinco.

O desvio radial era igual ou maior que $80 \%$ em 18 punhos, variando de 60 a $80 \%$ em cinco, de 40 a $60 \%$ em outros cinco e permanecendo abaixo de $40 \%$ em sete. O desvio ulnar estava igual ou maior que $80 \%$ em 18 punhos, entre 60 e $80 \%$ em 13 , entre 40 e $60 \%$ em um e menor que $40 \%$ em três.

A pronação era igual ou maior que $80 \%$ em 25 punhos, entre 60 e $80 \%$ em quatro, entre 40 e $60 \%$ em três e menor que $40 \%$ em outros três, e a supinação estava igual ou maior que $80 \%$ em 20 punhos, variando entre 60 e $80 \%$ em nove, entre 40 e $60 \%$ em três e permanecendo menor que $40 \%$ em outros três .

A avaliação estética mostrou que 20 punhos tinham aspecto normal, mas 11 tinham a cabeça da ulna saliente, três tinham o aspecto em "dorso de garfo" leve, dois tinham desvio radial e dois, desvio ulnar. Segundo a opinião dos próprios pacientes, o resultado do tratamento foi excelente em 15 punhos, bom em 13, regular em seis e mau em apenas um.

$\mathrm{Na}$ avaliação funcional segundo os critérios de Carazatto(9) a função era maior que 95\% do normal em 34 punhos, sendo igual a $85 \%$ do normal em apenas um. As forças de preensão manual e de pinça foram analisadas comparativamente com o lado contralateral, motivo pelo qual foram descartados quatro pacientes, três dos quais por apresentarem fraturas bilaterais e um por ter amputação do polegar e indicador na mão contralateral. Restaram 28 punhos efetivamente avaliados, dos quais 16 apresentaram força de preensão manual maior que $80 \%$, oito entre 60 e $80 \%$, e quatro menor de $60 \%$ do normal contralateral. Quanto à força da pinça polegar-indicador ponta-ponta, em 26 punhos foi maior que $80 \%$ e em apenas dois ficou entre 60 e $80 \%$ do normal contralateral.

\section{Avaliação Radiográfica}

Compreendeu a análise das radiografias finais de todos os pacientes selecionados, inclusive dos que não compareceram para reavaliação clínica e radiográfica, para os quais apenas o parâmetro da diastase escafo-semilunar não pode ser avaliado, por requerer incidência radiográfica especial obtida no comparecimento. A análise dos dados registrados mostrou que o ângulo de inclinação radial médio foi de $23^{\circ}$ (variação: $6^{\circ}$ - $30^{\circ}$ ), o ângulo de inclinação volar médio foi de $0,5^{\circ}$ (variação: $-16^{\circ}-20^{\circ}$ ) e a discrepância de comprimento radio-ulnar média foi de 2,75mm (variação: 0 - 26mm). O ângulo escafo-semilunar médio foi de $44^{\circ}$ (variação: $30^{\circ}-61^{\circ}$ ) e o ângulo luno-capitato médio foi de $10^{\circ}$ (variação: 0 a 45).

A diastase escafo-semilunar, medida apenas nos pacientes que compareceram para reavaliação, variou de 1 a 3mm (média: 1,4mm) e o sinal do anel no escafóide estava presente em 8 punhos. Sinais sugestivos de degeneração e artrose foram observados em 11 punhos.
Flexion was equal or superior to $80 \%$ of the normal in four wrists, ranging from 60 to $80 \%$ in 15, from 40 to $60 \%$ in 11 and under $40 \%$ in five.

Radial inclination was equal or superior to $80 \%$ in 18 wrists, ranging from 60 to $80 \%$ in five, from 40 to $60 \%$ in another five, and under $40 \%$ in seven. Ulnar inclination was equal or superior to $80 \%$ in 18 wrists, between 60 and $80 \%$ in 13 , between 40 and $60 \%$ in one and under $40 \%$ in three.

Pronation was equal or superior to $80 \%$ in 25 wrists, between 60 and $80 \%$ in four, between 40 and $60 \%$ in three and under $40 \%$ in another three. Supination was equal or superior to $80 \%$ in 20 wrists, ranging from 60 to $80 \%$ in nine, between 40 and $60 \%$ in three and under $40 \%$ in another three.

Regarding aesthetic evaluation, 20 wrists had normal appearance, however 11 had a salient ulnar head, three had a light "fork back" appearance; two had radial deviation and two ulnar deviation. According to the opinion of the patients, the results were excellent in 15 wrists, good in 13, fair in six and bad in only one.

Regarding functional evaluation according to Carazatto's criteria ${ }^{(9)}$, function was superior to $95 \%$ of the normal in 34 wrists, equal to $85 \%$ of the normal in only one. Grip strength and thumb/ index power were analyzed in comparison to counter-lateral side. For this reason, four patients were not evaluated, three of them due to bilateral fracture and one for amputation of thumb and index of counter-lateral hand. From the remaining 28 wrists, 16 had hand grip superior to $80 \%, 8$ between 60 and $80 \%$, and four under $60 \%$ of the counter-lateral normal. Regarding thumb/index power tip to tip, in 26 wrists it was superior to $80 \%$ and in only two was between 60 and $80 \%$ of counter-lateral normal.

\section{Radiographic Evaluation}

Involved the analysis of final radiography of all selected patients, including those who did not come for clinical and radiographic reevaluation. For these, only scapholunate diastasis was not evaluated, due to the need of a special radiographic exposure obtained at this additional visit. The analysis of the recorded data demonstrated an average radial angle of $23^{\circ}$ (range from $6^{\circ}$ to $30^{\circ}$ ), average volar angle was $0.5^{\circ}$ (range from $-16^{\circ}$ to $20^{\circ}$ ) and radio-ulnar length discrepancy averaged $2.75 \mathrm{~mm}$ (range from 0 to $26 \mathrm{~mm}$ ). Average scapholunate angle was $44^{\circ}$ (range: $30^{\circ}-61^{\circ}$ ) and average lunocapitate angle was $10^{\circ}$ (range: 0 a $\left.45^{\circ}\right)$

Scapholunate diastasis, evaluated only in those patients who returned for re-evaluation, ranged from 1 to $3 \mathrm{~mm}$ (average 1.4 $\mathrm{mm}$ ) and scaphoid ring sign was present in 8 wrists. Signs suggesting degeneration and arthrosis were observed in 11 wrists.

For all selected patients, independently of their return for reevaluation, according to Frykman as modified by Lidstrom ${ }^{(22,29)}$, excellent results were obtained in 21 wrists, good in another 21 , fair in five, and bad in three. Were also found 7 wrists with signs of VISI and 8 with signs of DISI. 
Ainda para todos os pacientes selecionados, independentemente de seu comparecimento ou não para a reavaliação, e segundo os critérios de Frykman modificados por Lidstrom ${ }^{(22,29)}$, foram obtidos resultados excelentes em 21 punhos, bons em outros 21, regulares em cinco e maus em três. Foram encontrados, ainda, 7 punhos com sinais de VISI e 8 com sinais de DISI.

\section{Complicações}

A análise das complicações também incluiu os pacientes que não compareceram para reavaliação. Assim, elas ocorreram em 11 punhos, a mais freqüente sendo a infecção superficial no trajeto dos pinos, que acometeu cinco punhos, seguida pela perda de redução, que ocorreu em três punhos. A infecção foi bem resolvida em todos os casos por meio de curativos e antibioticoterapia, mas a perda de redução necessitou de remanipulação da fratura e do fixador externo em todos os punhos, sendo que em dois foi necessária a fixação percutânea adicional com fios de Kirschner, e no outro foi necessária a redução aberta e fixação interna adicional com fios de Kirschner. A terceira complicação mais freqüente foi o afrouxamento de um pino apenas, que ocorreu em dois punhos, todavia sem necessitar de troca ou retirada antes do tempo previsto. Por último, houve um caso de Distrofia Simpática Reflexa, que produziu o pior resultado funcional.

\section{DISCUSSÃO}

As fraturas cominutivas da extremidade distal do rádio, principalmente aquelas dos tipos 7 e 8 da classificação de Frykman ${ }^{(15)}$, usualmente são de difícil tratamento pelos métodos convencionais. ${ }^{(1,3,4,5,13,14,15,16,24,28,30,31)}$ Elas envolvem, geralmente, mais de três fragmentos, cuja manipulação em conjunto e redução é praticamente impossível. Além disso, são invariavelmente instáveis, de modo que a manutenção da redução eventualmente obtida tornase difícil pelos meios convencionais. Por outro lado, a redução aberta e fixação interna dessas fraturas pelo método $\mathrm{AO}^{23}$ é de difícil execução, principalmente quando se levam em consideração as dimensões dos fragmentos, em geral muito pequenos para comportarem parafusos, e a osteoporose, comum nos pacientes idosos.

A combinação de pinos e aparelho gessado, como proposta por Boehler e vários outros autores ${ }^{(5,8,16,18,19,25,27,30,31)}$, é uma solução razoável, mas esse método se acompanha de um índice relativamente elevado de complicações, principalmente a infecção no trajeto dos pinos, pela impossibilidade de inspecioná-los e higienizá-los periodicamente. Além disso, o método é pouco prático para o caso, por exemplo, de uma remanipulação por perda de redução ${ }^{(10)}$. Assim, a evolução para os aparelhos de fixação externa foi praticamente um imperativo, pois eles são mais leves e cômodos para o paciente e permitem a limpeza diária da pele ao redor dos pinos, além de permitirem remanipulações periódicas. No caso do fixador externo utilizado (Biomecânica), convém salientar que a sua concepção não é a ideal, pois as barras rosqueadas rígidas conectam-se diretamente com os parafusos que fazem o ajuste e aperto das plataformas de fixação dos pinos de Shanz. Essa conexão não é móvel, de modo que, sempre que se façam necessárias as

\section{Complications}

Analysis of the complications also included the patients who did not come for reevaluation. They were observed in 11 wrists, and the most frequent was superficial infection around the nails, found in five wrists, followed by loosing the reduction, found in three wrists. Infection was well solved in all cases by means of cleaning and antibiotics. Loosing the reduction made necessary to re-manipulate the fracture and the fixator in all wrists, and in two it was necessary additional percutaneous Kirschner wire fixation. Another case needed open reduction and additional internal fixation with Kirschner wires. The third most frequent complication was loosening of a single nail, found in two wrists, however without need of replacement or removal before the expected time. One case of Reflex Sympathetic Dystrophy was also found, which lead to the worst result.

\section{DISCUSSION}

Comminuted fractures of distal radius, particularly those rated as 7 and 8 according Frykman(15), are usually difficult to treat through usual methods $(1,3,4,5,13,14,15,16,24,28,30,31)$. They generally involve more than three fragments, which are virtually impossible to manipulate in order to get a good reduction. Besides this, these fractures are usually instable, and keeping the reduction eventually obtained is very difficult by using the conventional resources. On the other hand, open reduction and internal fixation of these fractures by $\mathrm{AO}$ method $^{23}$ is very difficult to perform, mainly when the size of the fragments is considered, since they are generally too small to be screwed, and osteoporosis is common in elder patients.

Combination of wires and cast as proposed by Boehler and several other authors $(5,8,16,18,19,25,27,30,31)$, is a reasonable solution, however this method is frequently joined by a number of complications, especially infection due to the impossibility of viewing and cleaning the wires. And the method is not practical when it is the case of a re-manipulation due to a lost reduction (10). So, evolution of external fixators was imperative, since they are lighter and more comfortable for the patient, allowing daily cleaning of the skin around the nails, and periodic remanipulations when needed. In the case of the model of fixator used (Biomecanica), it is worthy to stress that its conception is not the ideal, since the rigid bars are connected directly to the screws that adjust and fix the Shanz nail fixating platforms. This connection is not mobile, making that when re-manipulations are need it is necessary release all the system and sometimes even to place new Shanz nails in more suitable placement. This kind of problem can be avoided by the use of more modern conception fixators, as the AO mini-fixator and others, which use independent platforms of fixation and much more versatile connecting bars.

In the retrospective phase of this work, the analysis of the files and the initial radiographies of each patient revealed that most of them had had a good evolution, with low complication rates, and those observed were almost always of minor importance and easy to manage. Only one case of Reflex Sympathetic Dystrophy happened, that could have been triggered 
remanipulações é preciso soltar todo o sistema e, às vezes, até mesmo introduzir novos pinos de Shanz em posições mais adequadas. Problemas desse tipo são evitados com o uso de fixadores de concepção mais moderna, como o mini-fixador $\mathrm{AO}$ e outros, que utilizam plataformas independentes de fixação dos pinos e das barras de conexão e são muito mais versáteis.

Na fase retrospectiva deste trabalho, a análise dos prontuários e das radiografias iniciais e finais de cada paciente já demonstrou que a maioria deles havia tido uma boa evolução, com um baixo índice de complicações, as quais foram, quase sempre, pouco importantes e de fácil controle. Houve apenas um caso de Distrofia Simpática Reflexa, que pode ter sido desencadeada tanto pela distração articular, que não era excessiva, como pelo tempo de imobilização, que foi de 10 semanas. Nesse particular, convém lembrar que a redução adequada dos fragmentos só é obtida à custa de algum grau de distração articular, a qual, todavia, só deve ser mantida por cerca de duas semanas, depois do que a tração deve ser reduzida para que o contato entre as superfícies articulares do rádio e dos ossos do carpo se restabeleça, sem o perigo de perda da redução. Ainda mais, o fixador deve ser mantido por no máximo 8 semanas, devendo então ser retirado e substituído por um aparelho gessado ou uma órtese de plástico termo-moldável, se ainda for necessária a imobilização.

Os resultados funcionais tardios, observados na reavaliação dos pacientes, foram de modo geral bons, principalmente se for levada em consideração a gravidade das fraturas. Houve recuperação de $60 \%$ ou mais dos movimentos nos vários planos em mais da metade dos pacientes, sendo que o movimento mais prejudicado foi a flexão, pois somente 19 dos 35 punhos reavaliados recuperaram mais de $60 \%$ da amplitude normal. Seguiu-se o desvio radial, limitado em $60 \%$ ou mais da amplitude normal em 23 dos 35 punhos reavaliados. O movimento que mostrou a maior recuperação foi o desvio ulnar, igual ou maior que $60 \%$ do normal em 31 dos 35 punhos reavaliados. Além disso, a função global do membro superior manteve-se em nível praticamente normal (95\% do desempenho máximo possível) em 34 dos punhos reavaliados, estando apenas um com menos de $90 \%$. A força de preensão manual, medida em 28 punhos, estava abaixo de $60 \%$ do normal em somente quatro punhos e acima de $80 \%$ em 16 , os restantes oito punhos estando entre esses limites. Já a força da pinça polegarindicador ponta-a-ponta foi maior que $80 \%$ do normal em 26 dos 28 punhos avaliados.

A reavaliação radiográfica mostrou que, na média, houve razoável restituição dos parâmetros normais. Assim, o ângulo de inclinação radial ficou em torno de $23^{\circ}$, mas o ângulo de inclinação volar foi em média de $0,5^{\circ}$, e a discrepância de comprimento rádioulnar foi de 2,75 mm, que correspondem a uma correção insuficiente da inclinação volar e um encurtamento importante do rádio. Além dos valores médios, há que levar em consideração as variações, pois houve casos em que o ângulo de inclinação radial mal passou de $0^{\circ}$ ou o ângulo de inclinação volar foi negativo $\left(-16^{\circ}\right)$. Embora isso tenha ocorrido em casos isolados, convém lembrar que esses números correspondem a resultados muito maus, que atestam que nem sempre a técnica da fixação externa funciona com eficiência.

À exemplo do que é mencionado na literatura ${ }^{(4)}$, algumas alterações carpais foram detectadas, sendo 7 VISI e 8 DISI, mas em by the traction, that was not excessive, or by the 10 weeks time of immobilization. It is convenient to remember that, regarding this issue, adequate reduction of the fragments is only obtained under a certain degree of articular distraction, which, however, should only be kept by about two weeks, and after this traction should be alleviated allowing contact between articular surfaces of radius and carpal bones be restored without danger of loosing the reduction. Additionally, the fixators should be placed for no more than 8 weeks, when should be removed and replaced by cast or orthesis made of thermo-moldable plastic, may immobilization is still needed.

Late functional results seen in patients' reevaluation were in general good, mainly when considering the severity of the fractures. Recovery of $60 \%$ or more of the movements in several plans was obtained in more than one half of the patients, and the most restricted movement was flexion, since only 19 of the 35 reevaluated wrists recovered more than $60 \%$ of the normal range of movement. Radial inclination followed, limited to $60 \%$ or more in its range in 23 of the 35 re-evaluated wrists. The best recovering movement was ulnar inclination, equal or superior to $60 \%$ of normal in 31 of the 35 re-evaluated wrists. Global function of upper limb was quite normal (95\% of the possible performance) in 34 of the re-evaluated wrists, and was below $90 \%$ in only one. Hand grip measured in 28 wrists was below $60 \%$ of the normal in only four wrists, and above $80 \%$ in 16 . The remaining eight wrists were between these limits. The power of thumb/index grip tip to tip was above $80 \%$ of the normal in 26 of the 28 evaluated wrists.

Radiographic reevaluation revealed that in average a reasonable restoration of normal parameters was obtained. The radial angle was around $23^{\circ}$, however the volar angle averaged $0.5^{\circ}$. Length discrepancy between radius and ulna was 2.75 $\mathrm{mm}$, corresponding to an insufficient correction of volar angle and an important shortening of the radius. Besides average values, it is necessary to take into consideration the range of variation, since there were cases where radial angle was barely above $0^{\circ}$ or volar angle was negative $\left(-16^{\circ}\right)$. Even though this was observed in isolated cases, it is worthy to remember that these figures correspond to very bad results, confirming that not always the external fixation technique works efficiently.

As in the literature (4), some carpal changes were observed, being $7 \mathrm{VISI}$ e $8 \mathrm{DISI}$, however in no case were observed complaints or functional changes due to them. Also degenerative changes were found in 11 wrists, most of them of a light or mild degree, not yet leading to important symptoms. These changes, however, are anyway related to the severity of the fractures, and not to the method of treatment. 
nenhum caso havia queixas ou alterações funcionais decorrentes dessas anomalias. Também, alterações degenerativas foram observadas em 11 punhos, mas a maioria de grau leve ou moderado, ainda não implicando em sintomas exuberantes. De qualquer modo, estas são alterações ligadas à gravidade das fraturas e não ao método de tratamento.

\section{CONCLUSÕES}

Tendo em vista a gravidade da maioria das fraturas estudadas, os resultados finais obtidos (bons resultados clínicos em $85 \%$ dos punhos, funcionais em $97 \%$ e anatômicos em $84 \%$ ) e a ocorrência de apenas uma complicação grave, os autores concluem que o método da fixação externa para o tratamento das fraturas cominutivas da extremidade distal do rádio nem sempre restaura a anatomia do osso, mas propicia recuperação funcional adequada. É, portanto, uma opção a ser considerada como de escolha para esse tipo de fratura.

\section{REFERÊNCIAS}

1. Abbaszadgan, H., Jonsson, U.\& von Silvers, K.: Prediction of instability of Colles fractures. Acta Orthop. Scand. 60: 646-650, 1989.

2.Anderson, R.\& O'Neil, G.: Comminuted fractures of the distal end of the radius. Surg.Gynecol.Obstet. 78: 434-440, 1944

3. Axelrod, T.S. \& McMurtry, R.Y: Open reduction and internal fixation of comminuted, intraarticular fractures of the distal radius. J. Hand Surg. 15A(1): 1-11, 1990.

4. Barbieri, C.H., Mazzer, N. \& Santiago, G.R.: Avaliação tardia das fraturas da extremidade distal do rádio, com particular atenção para as instabilidades carpais associadas. Rev. Brasil. Ortop.29(8): 591-596, 1994.

5.Barbieri, C.H., Yamashita, J.L., Yoshida, J.K. \& Barbieri P.H.P.: Fraturas cominutivas da extremidade distal do rádio: avaliação tardia de tração-fixação bipolar pelo método de Green. Rev. Bras. Ortop. 19: 73-80, 1984.

6. Barbieri, C.H. \& Mazzer, N.: Triradiate skin incision for dorsal approach to the wrist. J. Hand Surg. 21B: 21-23, 1996.

7. Bartosh R.A. \& Saldana, M.J.: Intraarticular fractures of the distal radius: A cadaveric study to determine if ligamentotaxis restores radiopalmar tilt. J. Hand Surg. 15A(1): 18-21, 1990

8. Böhler, L.: The treatment of fractures, 3rd. Ed., New York, Grune \& Stratton, 1932, pp 90-96.

9. Carazatto, J.G.: Teste de função motora da mão. Pesquisa em 200 pessoas normais. Dissertação de Mestrado, Área Ortopedia e Traumatologia, FMUSP, 1978

10. Chapman, D.R., Bennet, J.B., Bryan, W.J. \& Tullos,H.S.: Complications of distal radius fractures: pins and plaster treatment. J. Hand Surg. 7:509-512, 1982.

11. Charnley, J.: The closed treatment of common fractures. London, Churchill Livingstone, 1972

12. Cooney, W.P.: External Fixation of Distal Radial Fractures. Clin. Orthop. 180: 44-49, 1983.

13. Cooney, W.P., Dobyns, J.H. \& Linscheid, R.L.: Fractures and dislocations of the wrist In Rockwood, C.A., Green, D.P. \& Bucholz, R.W. (Eds.): Fractures in Adults, Philadelphia, J.B.Lippincott, 1991, pp 563-678.

14. Forgon, M. \& Mammel, E.: The external fixateur in the management of unstable Colles' fractures. Int. Orthop. 5: 9-14, 1981.

15. Frykman, G.: Fractures of the distal radius, including sequelae shoulder-handfinger syndrome, disturbance of the distal radio-ulnar joint and impairment of the nerve function. A clinical and experimental study. Acta Orthop. Scand. (Suppl.108), 1967.

\section{CONCLUSIONS}

Considering the severity of most of the studied fractures, the final results observed (good clinical results in $85 \%$ of the wrists, functional in $97 \%$ and anatomical in $84 \%$ ) and that only one severe complication was observed, the authors conclude that the external fixation method for treatment of comminuted fractures of the distal radial end not always restores the bone anatomy, but also allows an adequate functional recovery. It is so to be understood as the option of choice for this kind of fractures.
16. Green, D.P.: Pins and plaster treatment of comminuted fractures of the distal en of the radius. J. Bone Joint Surg.57A: 304-310, 1975.

17. Green, D.P.: Carpal dislocations and instabilities. In Green, D.P. (Ed.) Operative Hand Surgery, New York, Churchill Livingstone, 1993, pp 861-928.

18. Hoppenfeld, S.: Exame da mão e do punho. In: Propedeutica Ortopédica. Coluna e Extremidades, Rio de Janeiro, Livraria Ateneu, 1987, pp 59-107.

19. Ledoux, A., Ravis, A., Vanderghinst, M.: L'embrochage des fractures inférieures du radius. Rev.Chir.Orthop. 59: 427-438, 1973

20. Leung, K.S., Shen, W.Y., Tsang, H.K., Chiu, K.H., Leung, P.C., \& Hung, L.K.: An effective treatment of comminuted fractures of the distal radius. J. Hand Surg. 15A(1): 11-15, 1990

21. Leung, K.S., Shen, W.Y., Leung, P.C., Kinninmonth, A.W.G., Chang, J.C.W. \& Chan, G.P.Y.: Ligamentotaxis and bone grafting for comminuted fractures of the distal radius. J.Bone Joint Surg. 71B(5): 838-842, 1989.

22. Lidström, A.: Fractures of the distal end of the radius. A clinical and statistical study of the end results. Acta Orthop Scand (Suppl. 4), 1959.

23. Müller, M.E., Allgöwer, M., Schneider, R. \& Willenegger, H.: Manual of Internal Fixation (3rd. Ed.), Berlin, Spriger-Verlag, 1991, pp 476-478.

24. Mazzer, N., Barbieri, C.H., Lemos, F.G.P. \& Moya, S.P.: Correlação anatomo-funciona dos resultados finais das fraturas da extremidade distal do rádio. Rev. Bras. Ortop. 29(10): 759-766, 1994

25. McFarlane, J.A. \& Thomas, R.H.: Fixed skeletal traction in the treatment of certain fractures of the wrist. Can. Med. Assoc. J. 186: 417-428, 1976

26. Nakata, R.Y., Chand, Y., Matiko, J.D., Frykman, G.K. \& Wood, V.E.: External fixators for wrist fractures: A biomechanical and clinical study. J. Hand Surg. 10A(6): 845-851, 1985

27. Palmer, A.K.: Fractures of the distal radius. In Green, D.P. (Ed.) Operative Hand Surgery, New York, Churchill Livingstone, 1993, pp 929-972.

28. Ravis, A., Ledoux, A., Thiebault, A. \& Vanderghinst, M.: Bipolar fixation of fractures of the distal radius. Int. Orthop. 3: 89-96, 1979

29. Reis, F.B., Faloppa, F., Saone, R.P., Boni, J.R. \& Corvelo, M.C.: Fraturas do terço distal do rádio: Classificação e tratamento. Rev. Bras. Ortop. 29(5): 326-330, 1994.

30. Sarmiento, A., Pratt, G.W., Berry, N.C \& Sinclair, W.F.: Colles' Fracture. Functiona bracing in supination. J. Bone Joint Surg. 57A: 311-316, 1975.

31. Scheck, M.: Long term follow-up of treatment of comminuted fractures of the distal end of the radius by fixation with Kirschner wires and cast. J. Bone Joint Surg. 44A: 337-351, 1962. 